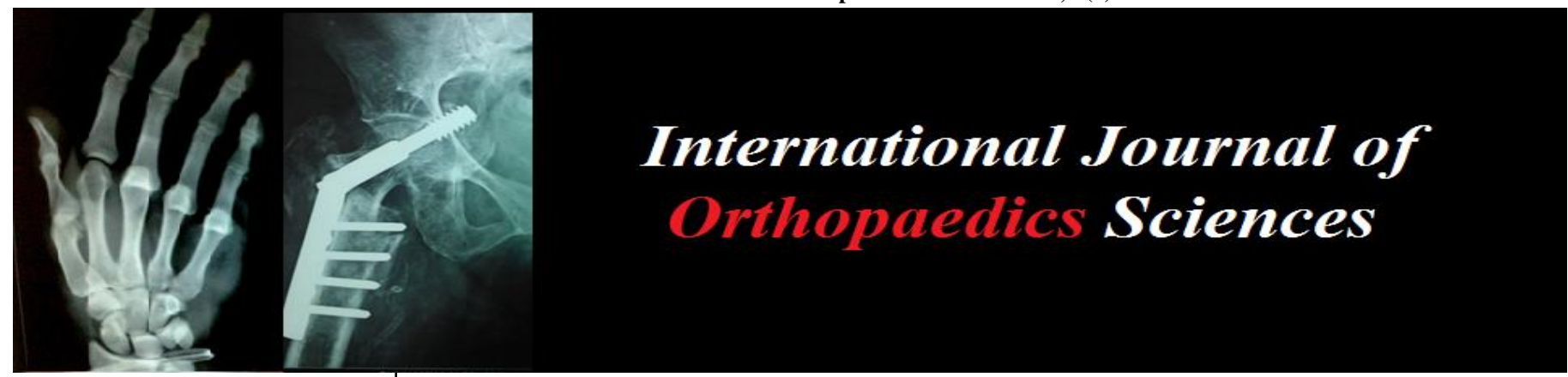

ISSN: $2395-1958$

IJOS 2018; 4(4): 144-148

(C) 2018 IJOS

www.orthopaper.com

Received: 25-08-2018

Accepted: 26-09-2018

\section{Dr. Satheesh GS}

Assistant Professor Department of Orthopedics Adichunchanagir Institute of Medical Science, B.G. Nagar, Bellur,

Nagamangala Taluk, Mandya District, Karnataka, India

\section{Dr. Harish K}

Assistant Professor

Department of Orthopaedic, Adichunchanagiri Institute of Medical Science B.G Nagar, Nagamangala, Taluk Mandya District, Karnataka, India

\section{Correspondence}

\section{Dr. Harish K}

Assistant Professor

Department of Orthopaedic, Adichunchanagiri Institute of Medical Science B.G Nagar, Nagamangala, Taluk Mandya District, Karnataka, India

\section{Comparative study of external fixation and flexible intramedullary nailing (Enders nailing) in open tibial fractures}

\section{Dr. Satheesh GS and Dr. Harish K}

DOI: https://doi.org/10.22271/ortho.2018.v4.i4c.25

\section{Abstract}

Background: Open tibia fracture, due to high energy or low enegy trauma classified according to Gustilo-Anderson classification system. The mode of fixation, been a subject of controvercy and some authors have proposed a need to address the issue of breach of soft tissue in these injuries.

Methods: The study included a total 50 patients of open tibia fractures managed in AHRC from june 2010 to june 2015.There was 10 patients of type II, 4 patients of type IIIA and 36 patients of type IIIB according to Gustilo-Anderson classification.29 patients were admitted to ORTHO A unit managed with enders nail where 21 patients admitted to ORTHO B unit managed with external fixator. The outcome was assessed by duration of fracture union, number of surgeries required, incidence of infection and malalignment.

Results: Open tibia fractures were mostly in males (90\%) where $70 \%$ were young patients with a mean age of 36.2.Among these patients $80 \%$ sustained high velocity injury. Mean period of fracture union in enders group were $25+-7$ weeks while in external fixator group was $39.4+-14$ weeks. Our study also reveals fractures associated with head injury united earlier.24 out of 29 cases managed by enders nail required $<3$ surgeries while 15/ 21 cases managed by external fixator required $>4$ furthur surgeries. Among these 50 cases infection detected in 12 cases (all were treated by external fixator; 11 cases belong to Gustilo-Anderson IIIB group). 35\% malalignment in external fixator group in comparison to $4 \%$ in patients treated with enders nail.

Conclusion: Open tibia fracture treated with ender nail united earlier than external fixator and total number of surgeries to achieve union in ender nail was significantly lesser than external fixator group. Infection and malalignment rate was also high in external fixation cases.

Keywords: External fixation, flexible intramedullary nailing, enders nailing, open tibial fractures

\section{Introduction}

There has been an increase in the number of road traffic accidents in the last decade. There are 60 fatal accidents/10,000 vehicles per year in India as compared to 2-3 fatal accidents/10,000 vehicles per year in developed countries. The incidence of open tibial diaphyseal fracture is high in polytrauma cases. They are frequently associated with infection, loss of limb and high levels of morbidity. The general consensus as to the five keys to the successful treatment of these fractures include: antibiotic therapy, radical debridement and pulsed lavage irrigation, stabilization of fracture with minimal further devascularization, early soft tissue coverage and early bone-grafting.

Delayed union or nonunion may be caused as a result of the treatment itself such as inadequate fixation or immobilization, distraction of fracture fragments, or excessive periosteal stripping, but in most cases the exact cause may not be very obvious. The optimum treatment for open fractures of the tibial shaft remains controversial. Despite improvements in surgical techniques in the last century, major problems with infection, malunion, and non-union have persisted. While it is widely accepted that emergency irrigation and soft-tissue debridement are the cornerstones of initial care, there is no consensus on the best method of obtaining and maintaining alignment and stability of the tibia. External fixation of these open fractures has been the treatment of choice in many medical centers, especially since the development of unilateral half-pin frames. 
Because of the major complications that are associated with external fixation, flexible nails that are inserted without reaming of the intra-medullary canal have been advocated for use in patients who have an open fracture. The purpose of this study was to compare the results of Ender nailing with those of external fixation in the management of open fractures of the tibial shaft.

\section{Aims and objectives}

To evaluate and compare the outcome of open tibial fractures treated by external fixation and flexible intramedullary nailing (enders nailing).

\section{Case selection criteria}

Inclusion criteria

Patients with open tibial fractures either as a solitary injury or with polytrauma.

\section{Exclusion criteria}

a) Open intra-articular fractures of either end of the tibia.

b) Open metaphyseal tibial fractures (those within $4 \mathrm{~cm}$ of the ankle or proximal to the tibial tubercle).

c) Fractures associated with a known neurovascular injury.

\section{Methods and material}

This study, conducted in the department of Orthopaedics, Adichunchanagiri Institute of Medical Sciences, B.G.Nagara. 50 Patients with open tibial diaphyseal fractures admitted in this hospital between June 2010 to June 2015 which were treated with Enders nailing and external fixator were included in this study. Our study is a prospective study. 21 Patients who were admitted in Ortho II UNIT where managed by External Fixator and 29 patients were admitted in ortho I Unit were managed with enders nailing.

Three weekly periodic follow up using AP and lateral roentgenograms were done.

Patients were assessed for union, range of motion at knee and ankle, Axial and rotational alignment of the limb, signs of infection.

\section{Statistical analysis}

Statistical analysis in our study was done with the help of SPSS version 14.0 (Statistical Package for Social Sciences V.14.0, For Windows, SPSS Inc. Chicago, Illinois). In case of two parametric variables we used Independent $t$ tests and in case of more than two parametric variables we used ANOVA tests. In case of non parametric variables we used Chi-Square tests. $\mathrm{P}$ value of less than 0.05 was taken as significant.

\section{Age of the Patients}

- Distribution of Sex of Patients

- Distribution of Side of Fracture

- Mode of Injury

- Associated Injuries

- Type of Flap Coverage

- Level of Fracture

- Gustilo and Anderson Classification

\begin{tabular}{|c|c|c|c|c|}
\hline parameter & & External fixation & Enders nail & P-value \\
\hline Age & & $39.4+/-13.3$ & $33.9+-11.3$ & 0.12 \\
\hline \multirow{2}{*}{ Sex } & Male & 18 & 27 & \\
\hline & Female & 04 & 01 & \\
\hline \multirow{2}{*}{ Side } & Right & 15 & 11 & \multirow{2}{*}{0.43} \\
\hline & Left & 07 & 17 & \\
\hline \multirow{2}{*}{ Trauma Mechanism } & High Energy & 17 & 26 & \multirow[b]{2}{*}{0.31} \\
\hline & Low Energy & 04 & 03 & \\
\hline \multirow{2}{*}{ Associated Injuries } & Present & 12 & 15 & \multirow{2}{*}{0.67} \\
\hline & Absent & 10 & 13 & \\
\hline \multirow{3}{*}{ Gestilo-Anderson Classification } & Type2 & 04 & 06 & \multirow{3}{*}{0.74} \\
\hline & Type $3 \mathrm{~A}$ & 01 & 03 & \\
\hline & Type 3B & 16 & 20 & \\
\hline \multirow{2}{*}{ Flap Coverage } & Required & 17 & 03 & \multirow{2}{*}{0.88} \\
\hline & Not Required & 04 & 06 & \\
\hline \multirow{2}{*}{ Types Of Flap Coverage } & Local Flap & 08 & 13 & \multirow{2}{*}{0.28} \\
\hline & Free Flap & 08 & 07 & \\
\hline \multirow{3}{*}{ Level Of The Fracture } & Middle1/3 & 04 & 08 & \multirow{3}{*}{0.193} \\
\hline & Middle To Upper $1 / 3$ & 03 & 09 & \\
\hline & Middle To Lower $1 / 3$ & 14 & 12 & \\
\hline
\end{tabular}

\section{Results}

Evaluation of outcome parameters in ender and external fixator group with respect to

A. Duration For Fracture Union
B. Number Of Surgeries Required

C. Incidence Of Infection

D. Malalignment

\begin{tabular}{|c|c|c|c|}
\hline Parameter & & Duration Of Fracture Union(Weeks) & P Value \\
\hline \multirow{2}{*}{ Fixation Method } & Enders Nail & $25+-7.03$ & \multirow{2}{*}{0.86} \\
\hline & External Fixation & $37.4+-14.44$ & \\
\hline \multirow{3}{*}{ Gestilo-Anderson Classification } & Type2 & $22.3+-7.43$ & \multirow{3}{*}{0.1} \\
\hline & Type3a & $22.4+-4.44$ & \\
\hline & Type $3 b$ & $29.8+-11.9$ & \\
\hline \multirow{3}{*}{ Level Of Fracture } & Middle1/3 & $26.7+-15.53$ & \multirow{3}{*}{0.9} \\
\hline & Middle-Upper $1 / 3$ & $27.9+-7.9$ & \\
\hline & Middle-Lower $1 / 3$ & $28.1+-10.4$ & \\
\hline \multirow{2}{*}{ Associated Injuries } & Ipsilateral & $28.7+-12.43$ & \multirow{2}{*}{0.4} \\
\hline & Contralateral & $29.5+-12.7$ & \\
\hline
\end{tabular}




\begin{tabular}{|c|c|c|c|}
\hline & Head Injury & $22.1+-4.2$ & \\
\hline \multirow{2}{*}{ Soft Tissue Coverage } & Required & $29.1+-11.6$ & \multirow{2}{*}{0.09} \\
\cline { 2 - 3 } & Not Required & $22.26+-7.4$ & \multirow{2}{*}{0.886} \\
\hline \multirow{2}{*}{ Types Of Flap } & Local Flap & $29+-11.49$ & $30.26+-12.78$ \\
\cline { 2 - 3 } & Free Flap &
\end{tabular}

\section{Discussion}

Tibia fractures are the most common fractures of long bones in the human body. 1 The tibial diaphysis is one of the most common sites of an open fracture 3, a fracture that involves a break in the skin and soft tissues communicating with the fracture or its hematoma, or both. The type of treatment selected for open tibial fractures depends on the individual characteristics of the fracture and the concomitant soft-tissue injury, making experience and clinical judgment an important part of the decision making during the formulation of treatment plan. 3, 10 The management of open fractures of the tibia may be complicated by infection, malunion, delayed union, or nonunion. Specific problems are inherent to every treatment method, making each method less than ideal. The advantages of external fixation include relatively stable fixation without additional soft tissue stripping, early range of motion of both knee and ankle, and unique adaptability to diverse fracture patterns. The disadvantages are, frequent pin tract problems, the potential for neurovascular damage during pin insertion, and the potential for fracture through a pin tract, cosmesis. In addition, the relative noncompliance of many patients may interfere with pin tract care and fixator durability. The advantages of intramedullary fixation include high patient acceptance, easiness for soft tissue coverage, control of alignment and rotation, early mobilization, and the potential for biomechanically safe early weight bearing. The major advantage of unreamed flexiable intramedullary nails is that alignment is maintained without additional periosteal damage and theoretically with minimal disruption of the medullary vasculature. The disadvantages include difficulty in controlling alignment of proximal one-third fractures, hardware failure due to the small nail size, and potential spread of infection throughout the medullary canal.

\section{Distribution of Age, Sex, Mode of injury and Associated injuries}

Open fractures evaluated in our study were mostly young males who had sustained high velocity trauma and more than half of them had multiple injuries. There were 45 males (90\%) and 5 females $(10 \%)$ in our series. Most of the patients were in the range of $21-40 \mathrm{yr}$ age group $(70 \%)$ with a mean age of $36.2(+/-) 12.4$ years. $86 \%$ of these patients sustained fractures due to road traffic accidents. $46 \%$ of the associated injuries were ipsilateral fractures some of which needed surgical intervention and $8 \%$ had head injury. This distribution of age, sex and mechanism of injury is very much in agreement with previous literature published in relation to open fractures $[24,25,26,32,48,49]$.

\section{Duration for fracture union}

The mean period for fracture union in our enders group was $25+/-7$ weeks, while in external fixator group the mean period was 37.4+/- 14 weeks though fractures managed by enders united early, the difference was not statistically significant. Our study was comparable with standard series ${ }^{[25,}$ 26, 27]. In our study, Enders group had more delayed union and external fixator group had more non union which is in contradictory to Holbrook et al. ${ }^{[25]}$ which showed rates of non-union were similar, but the rate of delayed union was considerably higher for the external-fixation group. In series Whitelaw et al. ${ }^{[26]}$ Both delayed union and non union were more in external fixator group.

\begin{tabular}{|c|l|l|l|l|l|l|}
\hline $\begin{array}{l}\text { Gustilo and } \\
\text { Anderson } \\
\text { Classification }\end{array}$ & \multicolumn{2}{|c|}{ Our study } & \multicolumn{2}{c|}{ Holbrook et al ${ }^{25}$} & \multicolumn{2}{c|}{${\text { Whitelaw et } \text { al }^{26}}^{26}$} \\
\hline & ENDERS & EXT FIX & ENDERS & EXT FIX & ENDERS & EXT FIX \\
\hline I & - & - & 19.6 & 19.2 & 21.2 & 17.3 \\
\hline II & 21.4 & 22.4 & 25.2 & 26.8 & 19.4 & 26.8 \\
\hline III & 26.1 & 29.3 & 27.2 & 29.6 & 24.6 & 27.9 \\
\hline AVERAGE & 25 & 37.4 & 23.6 & 26.4 & 21.7 & 26.7 \\
\hline
\end{tabular}

Type 2 and Type 3A fractures united early with mean duration of 22 weeks as compared to Type $3 \mathrm{~B}$ with mean duration of 29 weeks. This was comparable to Henley M.B.et al. 24 series which showed that more severe.

Distal third fractures took marginally higher time for union compared to proximal and middle third fractures. An anatomic factor that commonly determines the rate of union of tibial fractures is the degree of preservation of the tibial blood supply.

Fractures associated with head injury united faster. The results of matthew boes et al. 10 support data from previous studies have suggested an increased osteogenic potential and an enhancement of fracture-healing secondary to traumatic brain injury.
Number of Surgeries required for attaining fracture union Total number surgeries required for attaining fracture union was significantly high in external fixator group in comparison to enders group. While (24/29) of our enders cases required only 3 surgeries or less, (15/21) of our external fixator group needed 4 surgeries or more. In the present study external fixator group had more number of infection so to eradicate infection repeated debridment was done. In enders group secondary surgical procedures required were only bone grafting or intramedullary interlocking nailing and enders nail removal was done at the same time during IMIL nailing. Whereas external fixator group, required different secondary surgical procedures like bone grafting, open reduction and internal fixation, intramedullary interlocking nailing, and even ilizarow fixation in patients with severe infection which 
required bone resection. Our study was comparable to other series $[25,26,28,49]$.

\section{Incidence of infection}

We had 12 cases infection all were belonging to external fixator group.

Our results were comparable to G.P. Whitelaw et al. 26 series which had no infection in enders group. In series of Holbrook et al. ${ }^{[25]}$ has shown incidence of osteomyelitis was twice as high in the external-fixation group (14 compared with 7 per cent). Out of 12 patients who had infection 11 patients were belonging to Gustilo Anderson type Type IIIB. So the patients in whom soft tissue coverage required had good results with enders group. Our results were comparable to $G$. P.Whitelaw et al. ${ }^{[26]}$ Three cases of Osteomyelitis, 2 in grade II and 1 in grade IIIA, 2 patients developed major pin tract infection. In series of Holbrook et al., ${ }^{[25]}$ There were 4 infection in Gustilo Anderson type Type III and 3infection in Gustilo Anderson type Type II.

\begin{tabular}{|c|c|c|c|c|}
\hline \multirow{2}{*}{\multicolumn{2}{|c|}{ Parameter }} & \multicolumn{2}{|c|}{ Incidence Of Infection(N) } & \multirow{2}{*}{ P Value } \\
\hline & & Yes & No & \\
\hline \multirow{2}{*}{ Type Of Fixation } & Enders Nail & 0 & 29 & \multirow{2}{*}{0.00} \\
\hline & External Fixation & 12 & 09 & \\
\hline \multirow{3}{*}{ Gestilo-Anderson Classification } & Type 2 & 1 & 09 & \multirow{3}{*}{0.20} \\
\hline & Type 3A & 0 & 04 & \\
\hline & Type 3B & 11 & 25 & \\
\hline \multirow{2}{*}{ Wound Coverage } & Present & 11 & 29 & \multirow{2}{*}{0.246} \\
\hline & Absent & 01 & 09 & \\
\hline \multirow{2}{*}{ Flap Coverage } & Local Flap & 05 & 15 & \multirow{2}{*}{0.326} \\
\hline & Free Flap & 06 & 10 & \\
\hline \multirow{2}{*}{ No. Of Surgeries } & 3 Or Less & 03 & 27 & \multirow{2}{*}{0.005} \\
\hline & 4 or more & 09 & 11 & \\
\hline
\end{tabular}

\section{Malalignment}

External fixator group patients had more malalignment as compared to patients in enders group. This is consistent with other studies. G.P. Whitelaw et al 26 has noted 6(35\%) of malunion in external fixator group as compared to $2(4 \%)$ of malunion in enders group. In series of Holbrook et al 25 showed that Ender-nailing group had a significantly lower rate of malunion. Meta-analysis of Mohit Bhandari28 concluded that unreamed nails offer significant advantages in reducing malunion as comparedto external fixator. The results of this study demonstrate that though there was no statistically significant difference in the time required for union and malalignment, patients operated with external fixator underwent more number of secondary operative procedures than those operated with enders nailing. Infection was more in external fixator group. These findings are comparable to other prospective studies. We are aware of the fact that we have recruited a fewer numbers of patients, which reduces the power $(1-\beta)$ of the study. A larger randomized trial or may be a multi-center trial can further improve the interpretation of the results.

\section{Conclusion}

1. Open tibial fractures treated with enders nail united earlier than external fixator.

2. Total number of surgeries to achieve union in external fixator group was significantly higher.

3. Infection rate was significantly higher in external fixator group.

4. Malalignment was more common in external fixator group.

\section{References}

1. David Stewart G, Robert Kay M, David Skaggs L. Open Fractures in Children Principles of Evaluation and Management. The Journal of Bone and Joint Surgery (American). 2005; 87:2784-2798.

2. Rockwood CA. Fractures in Adults. 4th ed. Philadelphia: Lippincott-Raven, 1996.

3. Bartlett 3rd CS, Weiner LS, Yang EC. Treatment of type II and type III open tibia fractures in children. J Orthop
Trauma. 1997; 11:357-62.

4. Henley MB, Chapman JR, Agel J, Harvey EJ, Whorton AM, Swiontkowski MF. Treatment of Type II, IIIA, and IIIB Open Fractures of the Tibial Shaft: A Prospective Comparison of Unreamed Interlocking Intramedullary Nails and Half-Pin External Fixators. Journal of Orthopaedic trauma. 1998; 12(1):1-7.

5. John Holbrook L, Marc Swiontkowski F, Roy Sanders, Nashville, Tennessee. Treatment of Open Fractures of the Tibia Shaft Ender Nailing versus External Fixation A randomized, prospective comparison. Vanderbilt University Medical Center; Nashville. J Bone Joint Surg Am. 1989; 71:1231-1238.

6. Whitelaw GP, Wetzler M, Nelson A, Segal D, Flectcher $\mathrm{J}$, Hadely $\mathrm{N}$ et al. Enders rods versus External fixator in the Treatment of open tibial fracture. Clinical Orthopaedics and Related Research, 1990, 253.

7. Kubiak EN, Egol KA, Scher D, Wasserman B, Feldman D, Koval KJ. Operative treatment of tibial fractures in children: are elastic stable intramedullary nails an improvement over external fixation? J Bone Joint Surg Am. 2005; 87:1761-8.

8. Mohit Bhandari, Gordon Guyatt H, Marc Swiontkowski F, Emil Schemitsch H. Treatment of open fractures of the shaft of the tibia A Systematic Overview And MetaAnalysis J Bone Joint Surg [Br]. 2000; 82-B:62-8.

9. Paul Tornetta III, Marc Bergman, Neil Watnik, Gregg Berkowitz. Treatment of Grade-Iiib Open Tibial Fractures A Prospective Randomised Comparison Of External Fixation And Non-Reamed Locked Nailing J BoneJoint Surg (Br). 1993; 75-B:13-19.

10. Matthew Boes, Micheal Kain, Sanjeev karkar, Fred Nicholls, Dennis Culliane, Louis Gerstenfeld et al. Osteogenic Effects of Traumatic Brain Injury on Experimental Fracture-Healing. The Journal of Bone \& Joint Surgery · Jbjs. Org, 2006, 88-A.

11. Tolo VT. External skeletal fixation in children's fractures. J Pediatr Orthop. 1983; 3:435-42.

12. Tu, Yuan-Kun MD, Lin, Chih-Hung, Su, Jun-I MD, Hsu et al. Unreamed Interlocking Nail versus External Fixator for Open Type III Tibia Fractures. The Jounal of Trauma, 
Injury, Infection and Critical care. 1995; 39(2):361-367.

13. Peter Schandelmaier, Chritain Krettek. Superior results of Tibial Rodding versus External fixator in Grade 3B Fracture. Clinical Orthopaedics and Related Research. 1997; 342:164-172. 